Article

\title{
Comparison of Soaking Corms with Moringa Leaf Extract Alone or in Combination with Synthetic Plant Growth Regulators on the Growth, Physiology and Vase Life of Sword Lily
}

\author{
Faisal Zulfiqar ${ }^{1, *(\mathbb{D}}$, Adnan Younis ${ }^{1}$, Patrick M. Finnegan ${ }^{2}(\mathbb{D})$ and Antonio Ferrante ${ }^{3(\mathbb{C}}$ \\ 1 Institute of Horticultural Sciences, University of Agriculture, Faisalabad 38040, Pakistan; \\ adnanyounis@uaf.edu.pk \\ 2 School of Biological Sciences, University of Western Australia, 35 Stirling Highway, \\ Perth, WA 6009, Australia; patrick.finnegan@uwa.edu.au \\ 3 Department of Agricultural and Environmental Sciences, Università degli Studi di Milano, 1 Via Celoria 2, \\ 20133 Milano, Italy; antonio.ferrante@unimi.it \\ * Correspondence: ch.faisal.zulfiqar@gmail.com; Tel.: +92-344-7216320
}

Received: 24 October 2020; Accepted: 9 November 2020; Published: 17 November 2020

check for updates

\begin{abstract}
Gladiolus is in demand worldwide as a cut-flower or landscaping plant, because of its superior commercial and ornamental value. Application of plant-based biostimulants has gained interest in the horticulture industry as an innovative and promising approach to ensure enhanced and sustainable yields along with better product quality. The influence of pre-plant corm soaks supplemented to $5 \%(v / v)$ with an aqueous extract from Moringa oleifera leaves (MLE) either alone or in combination with $50 \mathrm{mg} / \mathrm{L}$ salicylic acid (SA) or $50 \mathrm{mg} / \mathrm{L}$ gibberellic acid (GA) on the vegetative, physiological, and ornamental characteristics of potted gladiolus (Gladiolus grandiflorus) was investigated. In general, the treatment order for greatest horticultural value for all the parameters examined was: MLE + SA + GA > MLE + GA or SA individually > MLE alone > water-only control. Compared to other treatments, corms soaked in MLE + SA + GA had the earliest sprout time (3.7 days earlier than control), shortest production time (11 days earlier than control), tallest plant $(159.5 \mathrm{~cm})$, greatest number of leaves per plant (8.85 leaves), greatest maximum leaf area $\left(66 \mathrm{~cm}^{2}\right)$, highest SPAD reading (112) and photosynthetic activity $\left(6.7 \mathrm{mmol} \mathrm{m}^{-2} \mathrm{~s}^{-1}\right)$, longest spike length $(91 \mathrm{~cm})$, greatest number of florets per spike (20 florets), longest vase life (14.8 days), greatest $\mathrm{N}(1.53 \%), \mathrm{P}(0.28 \%)$, and $\mathrm{K}(0.64 \%)$ concentrations, and largest corm diameter $(4.68 \mathrm{~cm})$ and mass $(22.25 \mathrm{~g})$. The highest total protein and proline concentrations were observed with the combined application of MLE + GA + SA. Our findings suggested that MLE either alone or in combination with other plant growth regulators not only increased the yield and quality of cut spikes, but also prolonged the vase life of cut gladiolus.
\end{abstract}

Keywords: cut flowers; gladiolus; gibberellic acid; photosynthetic activity; plant biostimulant; sustainable agriculture; salicylic acid; vase life

\section{Introduction}

Gladiolus (Iridaceae) is a monocotyledonous, herbaceous, perennial geophyte and cormous ornamental. Gladiolus is commercially planted by corms to produce cut flowers, and potted and garden ornamental plants. Cut gladiolus flowers highly rank in global floral markets with consistent demand throughout the year due to their unique ornamental value [1]. Thus, the demand for cut gladiolus continues to increase not only for local use, but also for export purposes in some countries [1,2]. 
However, maintaining cut flower quality is an important challenge for growers globally [3]. Successful cut flower production relies on several important factors, including a minimum production cost, and a short and predictable production time [4], as well as an extended post-harvest longevity [1].

Excessive use of synthetic fertilizers increase production costs, as well as increase potential environmental damage through nutrient leaching $[5,6]$. Therefore, there is increasing interest in finding sustainable solutions not only to minimize production costs and improving pre-harvest quality, but also for extending the post-harvest longevity of the bloom. In view of these challenges, the use of plant-derived biostimulants in horticultural crops has increased due to the economic, environmental, and biological advantages [7,8]. Among biostimulants, natural bioactive substances such as moringa (Moringa oleifera) leaf extract (MLE) have been shown to improve the pre- and post-harvest quality of horticultural crops [1,2,8]. The foliar application of MLE at various development stages of gladiolus not only improved the flowering quality, but also enhanced the post-harvest quality and longevity [1]. The advantageous effects of MLE are associated with the presence of a natural cytokinin, zeatin, vitamins, and minerals, which, when applied to plants, enhanced endogenous plant hormone biosynthesis, and ultimately enhanced growth and development [8].

The appropriate use of plant growth regulators (PGRs) in floriculture for lowering agronomic inputs is also a promising strategy. Salicylic acid (SA), a phenolic PGR, has been widely studied for its role in regulating plant growth and development, as well as the maintenance of postharvest longevity of cut flowers $[9,10]$. It is an endogenous regulator involved in plant defence activation that induces flowering [11]. Gibberellic acid (GA) is another well-known and important PGR that has been widely used in floriculture for promoting growth, flowering, quality, and post-harvest longevity [12-14].

In the present study, we evaluated the potential influence of MLE with or without SA and/or GA on the growth, physiology, flowering, and post-harvest longevity of gladiolus. The hypothesis was that soaking corms as a priming treatment with MLE with or without added SA and/or GA could enhance the growth, flowering quality, and post-harvest longevity of this important cut flower species.

\section{Results}

\subsection{Days to $50 \%$ Sprouting}

In gladiolus, the time to reach $50 \%$ corm germination significantly decreased $(p<0.0001)$ in response to all corm-soaking treatments compared to the water control (Table 1). The MLE treatment shortened the time to reach $50 \%$ germination by $25 \%$ ( 6.8 days) compared to the control (9.1 days). The addition of SA or GA with MLE did not shorten this time further over the treatment with MLE alone (6.5-6.8 days). However, the addition of both SA and GA to MLE significantly shortened the time to $50 \%$ germination by nearly another 1.5 days to $60 \%$ of the time needed for corms in the control treatment (Table 1).

Table 1. Effect of $24 \mathrm{~h}$ corm soaking on time to $50 \%$ germination, production time, and vegetative traits of gladiolus (Gladiolus grandiflorus cv. "Nova").

\begin{tabular}{|c|c|c|c|c|c|}
\hline * Treatments & $\begin{array}{l}50 \% \text { Germination } \\
\text { (Days) }\end{array}$ & $\begin{array}{l}\text { Production Time } \\
\text { (Days to Harvest) }\end{array}$ & Plant Height (cm) & $\begin{array}{l}\text { Leaves per Plant } \\
\text { (Number) }\end{array}$ & Leaf Area $\left(\mathrm{cm}^{2}\right)$ \\
\hline Control & $9.1 \mathrm{a}^{1}$ & $82.8 \mathrm{a}$ & $134.4 \mathrm{c}$ & $7.4 \mathrm{c}$ & $59.5 c$ \\
\hline MLE & $6.8 \mathrm{~b}$ & $75.0 \mathrm{~b}$ & $148.8 \mathrm{~b}$ & $8.5 b$ & $62.0 \mathrm{bc}$ \\
\hline MLE + SA & $6.6 \mathrm{~b}$ & $73.0 \mathrm{c}$ & $151.9 \mathrm{~b}$ & $8.6 \mathrm{ab}$ & $63.6 \mathrm{ab}$ \\
\hline $\mathrm{MLE}+\mathrm{GA}$ & $6.5 \mathrm{~b}$ & $72.0 \mathrm{~d}$ & $151.5 b$ & $8.6 \mathrm{ab}$ & $62.2 \mathrm{bc}$ \\
\hline MLE+SA + GA & $5.4 \mathrm{c}$ & $71.0 \mathrm{e}$ & $159.5 \mathrm{a}$ & $8.8 \mathrm{a}$ & $65.8 \mathrm{a}$ \\
\hline ** ANOVA $p$ value & $<0.0001$ & 0.0000 & $<0.0001$ & $<0.0001$ & $<0.0001$ \\
\hline
\end{tabular}

${ }^{1}$ Values are means $(n=20)$. Different letters indicate significant differences. Differences between means were compared by Tukey's HSD post-hoc test using all pairwise comparisons $(p<0.05)$. * MLE (5\% Moringa leaf extract), MLE + SA (5\% Moringa leaf extract + salicylic acid), MLE + GA (5\% Moringa leaf extract + gibberellic acid), MLE + SA + GA (5\% Moringa leaf extract + salicylic acid + gibberellic acid). ${ }^{* *}$ ANOVA: Analysis of variance (One way). 


\subsection{Days to Harvest}

There was a significant $(p<0.05)$ difference among corm soaking treatments regarding production time (days to harvest). Among the treatments, corms soaked in MLE + SA + GA had the shortest production time (71 days) relative to control (82.8 days) (Table 1).

\subsection{Growth Parameters}

Vegetative traits, i.e., plant height, number of leaves per plant, and leaf area were significantly $(p<0.0001)$ higher in treated plants than in control plants (Table 1). Corms soaked in MLE + SA + GA induced plant growth and development. This treatment showed the longest floral stem $(159.5 \mathrm{~cm})$, the highest number of leaves (8.9), and the greatest leaf area $\left(65.9 \mathrm{~cm}^{2}\right)$.

\subsection{Leaf Mineral Composition}

The effect of the treatments on macronutrient uptake was measured (Table 2). Corm soaking treatments $(p<0.0001)$ increased leaf concentrations of $\mathrm{N}, \mathrm{P}$ and $\mathrm{K}$ in gladiolus. The MLE + SA + GA treatment had highest $\mathrm{N}(1.53 \%), \mathrm{P}(0.28 \%)$, and $\mathrm{K}(0.64 \%)$ compared to all other treatments and the control (Table 2).

Table 2. Effect of soaking corms $(24 \mathrm{~h})$ in different treatment solutions on leaf concentrations of macro nutrients (N, P and $\mathrm{K} \%$ ) and leaf biochemical parameters (total soluble protein and proline) in gladiolus (Gladiolus grandiflorus cv. "Nova").

\begin{tabular}{|c|c|c|c|c|c|}
\hline${ }^{*}$ Treatments & Leaf N (\%) & Leaf P (\%) & Leaf K (\%) & $\begin{array}{c}\text { Total Soluble } \\
\text { Protein }\left(\mathrm{mg} \mathrm{g}^{-1} \mathrm{FW}\right)\end{array}$ & Proline $\left(\mu \mathrm{g} \mathrm{g}^{-1} \mathrm{FW}\right)$ \\
\hline Control & $0.94 \mathrm{e}^{1}$ & $0.15 d$ & $0.42 \mathrm{e}$ & $16.40 \mathrm{ab}$ & $22.70 \mathrm{c}$ \\
\hline $\mathrm{MLE}+\mathrm{SA}$ & $1.42 \mathrm{c}$ & $0.26 b$ & $0.59 b$ & $15.78 \mathrm{ab}$ & $23.06 c$ \\
\hline $\mathrm{MLE}+\mathrm{GA}$ & $1.45 b$ & $0.25 c$ & $0.56 c$ & $16.76 \mathrm{a}$ & $23.94 b$ \\
\hline $\mathrm{MLE}+\mathrm{SA}+\mathrm{GA}$ & $1.53 a$ & $0.28 \mathrm{a}$ & $0.64 a$ & $17.18 \mathrm{a}$ & $27.04 a$ \\
\hline
\end{tabular}

${ }^{1}$ Values are means $(n=20)$ and differences between means were compared by the post-hoc tukey test using all pairwise comparison at $p=0.05$. Mean pairs followed by different letters are significantly different. ${ }^{*}$ MLE (Moringa leaf extract 5\%), MLE + SA (Moringa leaf extract 5\% + Salicylic acid), MLE + GA (Moringa leaf extract $5 \%$ + gibberellic acid), MLE + SA + GA (Moringa leaf extract 5\% +Salicylic acid+ gibberellic acid). ** ANOVA: Analysis of variance (One way).

\subsection{Physiological and Biochemical Parameters}

Physiological parameters such as leaf greenness (SPAD) and photosynthetic rate showed significant difference among treatments (Table 3). Leaf chlorophyll non-destructively determined using SPAD and values ranged from 84.4 to 112.1. Control plants had the lowest value and MLE + SA + GA treatment had the highest value. The MLE-treated plants had an average SPAD value of 107.5. The addition of SA and GA had a synergistically positive effect. The positive effect was mainly induced by SA. The photosynthetic rate increased with the combination of treatments. As observed for leaf chlorophyll, the lowest value was found in the control plants $\left(4.7 \mathrm{mmol} \mathrm{m}^{-2} \mathrm{~s}^{-1}\right)$ and the highest values in the combined MLE + SA + GA treatment (6.69 $\left.\mathrm{mmol} \mathrm{m}^{-2} \mathrm{~s}^{-1}\right)$ (Table 3). 
Table 3. Effect of soaking corms $(24 \mathrm{~h})$ in different treatment solutions on corm size and plant physiological traits (SPAD, Photosynthesis rate) in gladiolus (Gladiolus grandiflorus cv. "Nova").

\begin{tabular}{ccccc}
\hline${ }^{*}$ Treatments & Corm Diameter $\mathbf{( c m )}$ & Corm Mass (g) & $\begin{array}{c}\text { Leaf Greenness } \\
\text { (SPAD) }\end{array}$ & $\begin{array}{c}\text { Photosynthesis Rate } \\
\mathbf{m m o l ~ m}^{-2} \mathbf{s}^{\mathbf{- 1})}\end{array}$ \\
\hline Control & $3.2 \mathrm{e}$ & $13.3 \mathrm{~d}$ & $84.4 \mathrm{c}$ & $4.6 \mathrm{~d}$ \\
MLE & $4.3 \mathrm{~d}$ & $16.6 \mathrm{~b}$ & $107.5 \mathrm{~b}$ & $5.6 \mathrm{c}$ \\
MLE + SA & $4.5 \mathrm{~b}$ & $16.7 \mathrm{~b}$ & $110.0 \mathrm{ab}$ & $6.0 \mathrm{bc}$ \\
MLE + GA & $4.4 \mathrm{c}$ & $15.6 \mathrm{c}$ & $108.1 \mathrm{ab}$ & $6.2 \mathrm{ab}$ \\
MLE + SA + GA & $4.6 \mathrm{a}$ & $22.2 \mathrm{a}$ & $112.1 \mathrm{a}$ & $6.6 \mathrm{a}$ \\
$*$ ANOVA Significance & $<0.0001$ & $<0.0001$ & $<0.0001$ & $<0.0001$ \\
\hline
\end{tabular}

${ }^{1}$ Values are means $(n=20)$ and differences between means were compared by the post-hoc tukey test using all pairwise comparison at $p=0.05$. Mean pairs followed by different letters are significantly different. ${ }^{*}$ MLE (Moringa leaf extract 5\%), MLE + SA (Moringa leaf extract 5\% + Salicylic acid), MLE + GA (Moringa leaf extract $5 \%+$ gibberellic acid), MLE + SA + GA (Moringa leaf extract $5 \%+$ Salicylic acid + gibberellic acid). ${ }^{* *}$ ANOVA: Analysis of variance (One way).

No effect was observed in the protein concentrations of corm-soaked plants compared to the controls (Table 2). Soaking corm in MLE alone or in combination with SA or GA caused a slight increase in the proline concentration, while the greatest increase in proline concentration $\left(27.04 \mu \mathrm{g} \mathrm{g}^{-1} \mathrm{FW}\right)$ was observed in MLE + SA + GA in comparison to the control (22.70) (Table 2).

\subsection{Corms Yield}

A significant increase $(p<0.0001)$ in corm diameter and biomass was observed in response to all corm soaking treatments compared to the control (Table 3). As a general trend, the maximum increase in these parameters was observed in treatment MLE + SA + GA.

\subsection{Ornamental Parameters}

Corm soaking treatments had significant positive effects on flower quality parameters. Spike length, florets per spike, flower quality, and vase life were higher in the treatments compared to the control. Treatment MLE + SA + GA showed the highest spike length $(91.08 \mathrm{~cm})$, the highest number of florets per spike (20 florets), and the longest vase life (14.82 days) (Table 4). However, corm soaking treatments did not affect stem thickness, which ranged from 9.7 to $10 \mathrm{~mm}$ (Table 4).

Table 4. Effect of corm soaking ( $24 \mathrm{~h}$ ) in different treatment solutions on the ornamental traits (spike length, florets per spike and vase life) of gladiolus (Gladiolus grandiflorus cv. "Nova").

\begin{tabular}{ccccc}
\hline${ }^{*}$ Treatments & Spike Length $\mathbf{( c m )}$ & Florets per Spike (No) & Vase Life (Days) & Stem Thickness (mm) \\
\hline Control & $86.2 \mathrm{~b}^{1}$ & $15.2 \mathrm{~b}$ & $11.3 \mathrm{c}$ & $9.7 \mathrm{a}$ \\
MLE & $92.3 \mathrm{a}$ & $18.7 \mathrm{a}$ & $13.0 \mathrm{~b}$ & $9.9 \mathrm{a}$ \\
MLE + SA & $93.4 \mathrm{a}$ & $19.4 \mathrm{a}$ & $12.4 \mathrm{bc}$ & $10.0 \mathrm{a}$ \\
MLE + GA & $89.2 \mathrm{ab}$ & $18.6 \mathrm{a}$ & $13.7 \mathrm{ab}$ & $9.8 \mathrm{a}$ \\
MLE + SA + GA & $91.0 \mathrm{a}$ & $20.0 \mathrm{a}$ & $14.8 \mathrm{a}$ & $9.8 \mathrm{a}$ \\
$* *$ ANOVA Significance & 0.0002 & $<0.0001$ & $<0.0001$ & 0.2567 \\
\hline
\end{tabular}

${ }^{1}$ Values are means $(n=20)$ and differences between means were compared by the post-hoc tukey test using all pairwise comparison at $p=0.05$. Mean pairs followed by different letters are significantly different. * MLE (Moringa leaf extract 5\%), MLE + SA (Moringa leaf extract 5\% + Salicylic acid), MLE + GA (Moringa leaf extract $5 \%+$ gibberellic acid), MLE + SA + GA (Moringa leaf extract $5 \%+$ Salicylic acid + gibberellic acid). ${ }^{* *}$ ANOVA: Analysis of variance (One way).

\section{Discussion}

Gladiolus is an important floriculture crop widely grown as cut flowers or landscaping plants, because of its beautiful spikes and long period of flowering [1]. The high economic costs, and environmental and health-related issues of using agrochemicals are a serious challenge to growers [1]. Natural biostimulants can be innovative tools for improving the yield and quality of ornamental plants. They can be cheaper, safer, and more environmentally friendly than common agrochemicals. There is 
great interest in replacing synthetic agrochemicals with biostimulants [8]. Results clearly revealed that the application of MLE along with SA or GA can be used as a potential plant growth regulator to enhance the growth, physiology, and vase life of gladiolus, making this approach an economically viable option to replace synthetic fertilizers. The time to $50 \%$ corm sprouting and days to harvest were also shortened in response to all corm soaking treatments, but the most effective treatment was the combination of MLE with SA and GA.

Positive effects of GA have been observed in other bulb plants. In particular $\mathrm{GA}_{3}$ treatments were applied to nine tulip cultivars to break bulb dormancy. $\mathrm{GA}_{3}$ application increased sprouting, growth of floral stalks, and flowering in all cultivars studied [15]. Pre-planting application of $\mathrm{GA}_{3}$ to tulip bulbs resulted in earlier sprouting, higher sprouting percentage, higher photosynthetic rates and improved plant growth. The most efficient concentrations were 100 or $150 \mathrm{mg} \mathrm{L}^{-1}$ [16].

Faster corm sprouting and shorter times to harvest are important parameters for bulbous crops and have many advantages for growers, such as earlier and quicker returns on investment and minimizing the impact of unfavorable conditions that typically occur in late season. Uniform corm sprouting minimizes the labor and corm price expenses for replanting. Our results on these parameters agree with the findings of other researchers, e.g., Ahmad et al. [17] on freesia cut flowers and Nau [18] on calla lily. These results could be due to the presence of endogenous plant cytokinins (dihydrozeatin, isopentyladenine, and zeatin) in MLE $[19,20]$. Zeatin is a naturally and abundant endogenous cytokinin in plants that is vital for important biological processes, including cell division, cell elongation, anti-aging potential, growth enhancement, and protection [21,22]. In gladiolus, soaking treatment with GA showed a positive effect on breaking corm dormancy, promoting growth, and flowering [23]. Furthermore, MLE is an enriched source of micronutrients and various other growth promoting substances that enhancing plant growth [8].

Corm soaking or priming with plant growth regulators is a common practice in ornamental cut flower production. However, combined application of biostimulants with plant growth regulators has not been tested and their effect may vary with cultivars, crops, and dose. Our results showed an increase of plant development in response to all corm soaking treatments, particularly in MLE + SA + GA. The growth-promoting impact of MLE in combination with GA and SA alone and in combination may be due to the positive effect of these substances on cell division, enhancing cell and stem elongation, leaf expansion, plant growth, flowering, and senescence [24,25]. Bulb soaking in GA increased germination percentage, plant height, leaves per plant, and leaf area of tulip (Tulipa gesneriana) [16]. Soaking freesia corms in MLE improved corm budding percentage, growth, and ornamental traits as compared to the untreated corms [17]. With regard to GA, Bergman et al. [4] also reported a positive influence of GA application on the growth and ornamental traits of poinsettia 'Renaissance Red'. Plant physiological traits are important indicators of improved plant function. SA is an important signal molecule that can activate different defense mechanism in plants [26]. The stress signal induced in the corm during priming could activate tolerance to biotic and abiotic stresses that helped the plants during the first stage of development.

In our study, corm soaking treatments increased the SPAD value and photosynthetic activity of gladiolus during cultivation. The increase in leaf area and chlorophyll concentration can explain the higher photosynthetic rate and better plants performance. At the biochemical level, these increases likely mean higher sugar production and biomass accumulation with a positive effect on growth and flower development. An increase in chlorophyll concentration in biostimulant-treated plants is a common physiological marker for the activation of primary metabolism [27]. A potential reason for an increase chlorophyll and photosynthetic activity may be the presence of substances promoting chlorophyll biosynthesis [28] in moringa leaves, including carotenoids and minerals [29,30]. GA is also an important plant hormone involved in the chlorophyll biosynthesis and stem elongation [31]. Increased chlorophyll concentration following MLE application correlates with a delay in leaf senescence due to the presence of ascorbate, zeatin, and potassium in MLE [30]. An increase in mineral concentration and plant physiological traits may result in improved ornamental quality and vase life. In a similar study, soaking 
gladiolus corms in 5\% MLE resulted in improved ornamental quality and vase life [17]. The increase in leaf proline concentration in the combined treatment suggested that this treatment could act in the reduction of the stress condition of the plant and increase the crop performance.

\section{Materials and Methods}

\subsection{Solutions}

Fresh mature moringa leaves $(100 \mathrm{~g})$ were harvested from a mature plant grown at the experimental area of the Department of Forestry, Range and Wildlife Management at the University of Agriculture, Faisalabad, Pakistan $\left(31^{\circ} 25^{\prime} 30^{\prime \prime} \mathrm{N} 73^{\circ} 04^{\prime} 15^{\prime \prime} \mathrm{E}\right)$. After harvesting, the leaves were washed with tap water to remove dust and debris. After drying in the shade for $1 \mathrm{~h}$, leaves were stored at $-5{ }^{\circ} \mathrm{C}$ overnight. Stored leaves were pressed and filtered twice using cheese cloth and Whatman filter paper no 1 [32,33]. The filtered extract was centrifuged at $8000 \times g$ for $15 \mathrm{~min}$ to remove fine debris. The supernatant was diluted with 20 volumes of distilled water to make a 5\% (v/v) MLE working solution. MLE had the following mineral composition on a dry weight basis: $6.70 \mathrm{mg} \mathrm{g}^{-1} \mathrm{Mg}^{2+}$, $28.0 \mathrm{mg} \mathrm{g}^{-1} \mathrm{Ca}^{2+}, 0.75 \mathrm{mg} \mathrm{g}^{-1} \mathrm{Na}^{+}, 25.1 \mathrm{mg} \mathrm{g}^{-1} \mathrm{~K}^{+}, 8.10 \mathrm{mg} \mathrm{g}^{-1} \mathrm{P}, 0.84 \mathrm{mg} \mathrm{g}^{-1} \mathrm{Mn}, 1.60 \mathrm{mg} \mathrm{g}^{-1}$ $\mathrm{Fe}^{2+}, 0.27 \mathrm{mg} \mathrm{g}^{-1} \mathrm{Zn}+$, and $0.14 \mathrm{mg} \mathrm{g}^{-1} \mathrm{Cu}^{2+}$ [30]. Furthermore, the extract also contained soluble phenolics (6.20 mg g-1), proline (21.00 mg g-1 DW), total carotenoids $\left(3.10 \mathrm{mg} \mathrm{g}^{-1}\right)$, ascorbic acid

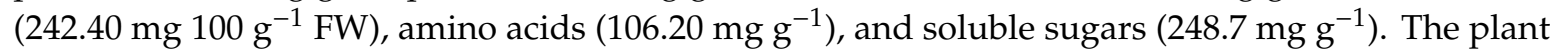
hormones present in MLE were indole-3 acetic acid (0.83), GA (0.74), zeatin (0.96), a cytokinin and abscisic acid (0.29) [30].

GA (50 mg L ${ }^{-1}$; Sigma Aldrich Corp., St. Louis, MO, USA) and SA (50 mg L ${ }^{-1}$; Sigma Aldrich Corp., St. Louis, MO, USA) were dissolved in 5\% (v/v) MLE either alone [(MLE 5\%), (MLE 5\% + GA $50 \mathrm{mg} \mathrm{L}^{-1}$ ) or (MLE 5\% + SA $50 \mathrm{mg} \mathrm{L}^{-1}$ )] or in combination (MLE $5 \%+$ GA $50 \mathrm{mg} \mathrm{L}^{-1}+\mathrm{SA} 50 \mathrm{mg} \mathrm{L}^{-1}$ ). Corms were soaked in these solutions or distilled water as a negative control for $24 \mathrm{~h}$ at $20^{\circ} \mathrm{C}$ in darkness.

\subsection{Experimental Setup}

A pot experiment was conducted at the Lalazar Nursery Area, University of Agriculture, Faisalabad $\left(31^{\circ} 25^{\prime} 36^{\prime \prime} \mathrm{N} 73^{\circ} 04^{\prime} 15^{\prime \prime} \mathrm{E}\right)$. Healthy and equal-sized corms (mean weight $4.5 \mathrm{~g}$; mean diameter $10 \mathrm{~cm}$ ) of gladiolus (Gladiolus grandiflorus) 'Nova' were surface sterilized with 5\% (v/v) NaOCl for 6 min, washed with double-distilled water and left to dry in shade. Corm scales were removed and soaked for $24 \mathrm{~h}$ in freshly prepared solutions of 5\% MLE, 5\% MLE + SA, 5\% MLE + GA and 5\% MLE + SA + GA. After soaking, corms were dried in the open air in shade at ambient temperature and planted in soil-filled plastic pots. The bulbs were planted on $20 \mathrm{Sep}, 2019$. The characteristics of the soil were: $0.655 \%$ organic matter, pH 7.2; EC ( $\left.\mathrm{dSm}^{-1}\right)$ 0.92; $0.028 \% \mathrm{~N} ; 9.8 \mathrm{mg} \mathrm{kg}^{-1}$ available $\mathrm{P}$ and $203 \mathrm{mg} \mathrm{kg}^{-1}$ exchangeable K.

\subsection{Plant Vegetative and Reproductive Growth}

The time to $50 \%$ corm sprouting (sprouted $=$ the young buds reach one centimeter in length) and days to production harvest (from planting to complete flowering) were counted. Plant height, total number of leaves per plant, and leaf area (LICOR-3000C Portable Area Meter; LI-COR, Lincoln, NE, USA) were measured. Inflorescence/spike length, number of florets per spike, and stem thickness were measured. At the time of spike harvest, two lower leaves were left intact to support corm development [1]. On maturity, corms were uprooted and washed with tap water. Corm mass and diameter were measured.

\subsection{Vase Life Determination}

Flower spikes free from visual defects were harvested with a sharp steel knife during the morning hours at the commercial maturity stage, i.e., uniformity in size and quality, 2 to 3 florets per spike in 
color break stage. After harvest, the cut spikes were placing upright in a bucket partially filled with water and moved to the laboratory within $15 \mathrm{~min}$. Moisture loss was minimized by shrouding the cut flowers with soft plastic film during the move. In the laboratory, spikes were re-cut at approximately $90 \mathrm{~cm}$ length under water to minimize air emboli and vascular blockage. One spike per vase were placed in $200 \mathrm{~mL}$ vases filled with deionized distilled water and covered with aluminum foil to prevent evaporation. Vases were kept at $25 \pm 2{ }^{\circ} \mathrm{C}$, relative humidity $60 \pm 5 \%$, under white fluorescent lamps with a $14 \mathrm{~h}$ light $10 \mathrm{~h}$ dark photoperiod. A total of 20 cut flower spikes were used per treatment to assess vase life. The end of vase life was defined as the number of days from harvest until $60 \%$ of the flower petals had wilted or had no aesthetic value due to loss of turgidity or color changes. Data were recorded daily up to 15 days.

\subsection{Leaf Physiological Parameters and Mineral Concentrations}

Leaf greenness index measurements (SPAD 502, Konica Minolta, Japan) were taken from base, middle and tip of fully expanded leaves at the phenological stage of full flowering of plants. Net photosynthetic carbon assimilation rate $\left(\mu \mathrm{mol} \mathrm{m}^{-2} \mathrm{~s}^{-1}\right)$ was measured at the phenological stage of full flowering of plants on three mature, healthy, and fully expanded sunlit leaf blades from six plants per treatment between 9.00 am and 11.00 am using an infrared gas analyzer (LI-COR 6400, LI-COR, Lincoln, NE, USA) set at $400 \mu \mathrm{mol} \mathrm{m} \mathrm{m}^{-2} \mathrm{~s}^{-1} \mathrm{CO}_{2}$ and a flow rate of $300 \mu \mathrm{mol} \mathrm{m}^{-2} \mathrm{~s}^{-1}$. Leaf nitrogen (N) concentration was determined by the Kjeldhal method according to Jackson [34]. Leaf phosphorus (P) and potassium $(\mathrm{K})$ concentrations were determined according to Chapman and Pratt [35].

\subsection{Total Soluble Proteins and Leaf Free-Proline Contents}

Total soluble protein was determined at $595 \mathrm{~nm}$ using bovine serum albumin as a standard [36]. A ninhydrin-based method was used to measure leaf free-proline concentration [37]. Briefly, $0.5 \mathrm{~g}$ fresh leaf material was extracted in $10 \mathrm{~mL}$ of $3 \%(w / v)$ sulfo-salicylic acid. Afterwards, $2.0 \mathrm{~mL}$ of the filtered solution was added to $2.0 \mathrm{~mL}$ of acid ninhydrin $(1.26 \mathrm{~g}$ ninhydrin $+20 \mathrm{~mL} 6 \mathrm{M}$ ortho-phosphoric acid $+30 \mathrm{~mL}$ glacial acetic acid) and $2.0 \mathrm{~mL}$ of glacial acetic acid. Samples were incubated at $80{ }^{\circ} \mathrm{C}$ for $60 \mathrm{~min}$ and immediately moved to an ice bath to terminate the reaction. Toluene $(4.0 \mathrm{~mL})$ was added to the solution and vigorously mixed by vortexing for $30 \mathrm{~s}$. The chromophore-containing toluene was separated from the aqueous phase and its absorbance read at $520 \mathrm{~nm}$.

\subsection{Experimental Design and Statistical Analysis}

The experiment was performed in a completely randomized fashion with twenty plants per treatment and a total 5 treatments (MLE, MLE + GA, MLE + SA, MLE + SA + GA, and control) for a total of 100 plants. Data were analyzed via ANOVA. Means were separated using all comparisons through Tuckey's HSD test $(p \leq 0.05)$ (statistix 8.1 Analytical Software, Tallahassee, FL, USA).

\section{Conclusions}

Agricultural systems are evolving towards more economic and environmentally friendly cultivation strategies. Biostimulants are greatly enhancing crop performance, thereby reducing agrochemical inputs, without compromising the quality and yield of crops. In the present work, a pre-planting treatment of soaking corms in combinations MLE and plant growth regulators (GA and SA) has been demonstrated to be an inexpensive and efficient system for enhancing plant performance. The results indicated that the addition of bioactive molecules in combination with plant growth regulators has a synergistic effect on cut gladiolus growth and development. At a practical level, these results allow for the modulation of the crop growth cycle such that the combined MLE treatment can also be exploited in the programming of flowering, which is extremely important to the ornamental sector. These encouraging results open the possibility for further studies focused on optimizing the concentration, timing, and mode of application of MLE alone or in combination with various plant growth regulators. 
Author Contributions: Conceptualization, F.Z. and A.Y.; methodology, F.Z. and A.Y.; resources, F.Z.; formal analysis, F.Z. and A.Y.; writing-original draft preparation, F.Z.; writing-review and editing, F.Z., A.Y., P.M.F., and A.F.; supervision, A.Y.; All authors have read and agreed to the published version of the manuscript.

Funding: This research received no external funding.

Acknowledgments: The authors are grateful to Shahzad. M. Basra for providing moringa leaf extract.

Conflicts of Interest: The authors declare no conflict of interest.

\section{References}

1. Younis, A.; Akhtar, M.S.; Riaz, A.; Zulfiqar, F.; Qasim, M.; Farooq, A.; Tariq, U.; Ahsan, M.; Bhatti, Z.M. Improved cut flower and corm production by exogenous moringa leaf extract application on gladiolus cultivars. Acta Sci. Pol. Hortorum Cultus 2018, 17, 25-38. [CrossRef]

2. Hassan, F.; Fetouh, M.I. Does moringa leaf extract have preservative effect improving the longevity and postharvest quality of gladiolus cut spikes? Sci. Hortic. 2019, 250, 287-293. [CrossRef]

3. Mollaei, S.; Farahmand, H.; Tavassolian, I. The effects of 24-epibrassinolide corm priming and foliar spray on morphological, biochemical, and postharvest traits of sword lily. Hortic. Environ. Biotechnol. 2018, 59, 325-333. [CrossRef]

4. Bergmann, B.A.; Dole, J.M.; Fisher, P.; Njue, G.; McCall, I. Gibberellic acid promotes flower stem elongation in 'Renaissance Red'poinsettia. Can. J. Plant Sci. 2016, 97, 14-16.

5. Ayyub, C.M.; Haidar, M.W.; Zulfiqar, F.; Abideen, Z.; Wright, S.R. Potato tuber yield and quality in response to different nitrogen fertilizer application rates under two split doses in an irrigated sandy loam soil. J. Plant Nutr. 2019, 42, 1850-1860. [CrossRef]

6. Zulfiqar, F.; Navarro, M.; Ashraf, M.; Akram, N.A.; Munné-Bosch, S. Nanofertilizer use for sustainable agriculture: Advantages and limitations. Plant Sci. 2019, 289, 110270. [CrossRef]

7. Colla, G.; Rouphael, Y. Biostimulants in horticulture. Sci. Hortic. 2015, 196, 1-2. [CrossRef]

8. Zulfiqar, F.; Casadesús, A.; Brockman, H.; Munné-Bosch, S. An overview of plant-based natural biostimulants for sustainable horticulture with a particular focus on moringa leaf extracts. Plant Sci. 2020, 295, 110194. [CrossRef]

9. Saeed, T.; Hassana, I.; Abbasia, N.A.; Ghulam-Jilani, G. Antioxidative activities and qualitative changes in gladiolus cutfowers in response to salicylic acid application. Sci. Hortic. 2016, 210, 236-241. [CrossRef]

10. Shabanian, S.; Esfahani, M.N.; Karamian, R.; Tran, L.S.P. Salicylic acid modulates cutting-induced physiological and biochemical responses to delay senescence in two gerbera cultivars. Plant Growth Regul. 2018, 87, 245-256. [CrossRef]

11. Fu, L.; Tan, D.; Sun, X.; Ding, Z.; Zhang, J. Transcriptional analysis reveals potential genes and regulatory networks involved in salicylic acid-induced flowering in duckweed (Lemna gibba). Plant Physiol. Biochem. 2020, 155, 512-522. [CrossRef]

12. Zulfiqar, F.; Younis, A.; Abideen, Z.; Francini, A.; Ferrante, A. Bioregulators Can Improve Biomass Production, Photosynthetic Efficiency, and Ornamental Quality of Gazania rigens L. Agronomy 2019, 9, 773. [CrossRef]

13. Bergmann, B.A.; Dole, J.M.; McCall, I. Gibberellic Acid Shows Promise for Promoting Flower Stem Length in Four Field-grown Cut Flowers. Hort. Technol. 2016, 26, 287-292. [CrossRef]

14. Saeed, T.; Hassan, I.; Abbasi, N.A.; Jilani, G. Effect of gibberellic acid on the vase life and oxidative activities in senescing cut gladiolus flowers. Plant Growth Regul. 2014, 72, 89-95. [CrossRef]

15. Rudnicki, R.; Nowak, J.; Saniewski, M. The effect of gibberellic acid on sprouting and flowering of some tulip cultivars. Sci. Hortic. 1976, 4, 387-397. [CrossRef]

16. Ramzan, F.; Younis, A.; Riaz, A.; Ali, S.; Siddique, M.I.; Lim, K.-B. Pre-planting exogenous application of gibberellic acid influences sprouting, vegetative growth, flowering, and subsequent bulb characteristics of 'Ad-Rem' tulip. Hortic. Environ. Biotechnol. 2014, 55, 479-488. [CrossRef]

17. Ahmad, I.; Tanveer, M.U.; Liaqat, M.; Dole, J.M. Comparison of corm soaks with preharvest foliar application of moringa leaf extract for improving growth and yield of cut Freesia hybrida. Sci. Hortic. 2019, 254, 21-25. [CrossRef]

18. Ball RedBook: Greenhouse growing. Choice Rev. Online 1992, 29, 29. [CrossRef]

19. Fuglie, L.J. The Miracle Tree: Moringa oleifera: Natural Nutrition for the Tropics. The Multiple Attributes of Moringa. Int. J. Adv. Res. Ideas Innov. Tehnol. 2000, 3, 172. 
20. Price, M. The Moringa Tree. ECHO Technical Note, eBook. 2007. Available online: http://wwwmiracletrees. org./Moringa-doc/ebookMoringapdf (accessed on 12 October 2019).

21. Nagar, P.K.; Iyer, R.I.; Sircar, P.K. Cytokinins in developing fruits of Moringa pterigosperma Gaertn. Physiol. Plant 1982, 55, 45-50. [CrossRef]

22. Anwar, F.; Latif, S.; Ashraf, M.; Gilani, A.H. Moringa oleifera: A food plant with multiple medicinal uses. Phytother. Res. 2007, 21, 17-25. [CrossRef] [PubMed]

23. Sajjad, Y.; Jaskani, M.J.; Mehmood, A.; Qasim, M.; Akhtar, G. Alleviation of gladiolus (Gladiolus grandiflorus) corm dormancy through application of 6-benzylaminopurine and gibberellic acid. Pak. J. Bot. 2019, 52, 831-838. [CrossRef]

24. Hedden, P.; Sponsel, V.M. A Century of Gibberellin Research. J. Plant Growth Regul. 2015, 34, 740-760. [CrossRef] [PubMed]

25. Prajapati, S.; Sharma, S.K.; Kadwey, S. Salicylic Acid a multifaceted hormone for vegetable crops-A Review. Trends Biosci. 2015, 8, 1179-1185.

26. Van Butselaar, T.; Ackerveken, G.V.D. Salicylic Acid Steers the Growth-Immunity Tradeoff. Trends Plant Sci. 2020, 25, 566-576. [CrossRef]

27. Bulgari, R.; Franzoni, G.; Ferrante, A. Biostimulants Application in Horticultural Crops under Abiotic Stress Conditions. Agronomy 2019, 9, 306. [CrossRef]

28. Yameogo, C.W.; Bengaly, M.D.; Savadogo, A.; Nikiema, P.A.; Traore, S.A. Determination of Chemical Composition and Nutritional Values of Moringa oleifera Leaves. Pak. J. Nutr. 2011, 10, 264-268. [CrossRef]

29. El Sohaimy, S.A.; Hamad, G.M.; Mohamed, S.E.; Amar, M.H.; Al-Hindi, R.R. Biochemical and functional properties of Moringa oleifera leaves and their potential as a functional food. Global Adv. Res. J. Agric. Sci. 2015, 4, 188-199.

30. Rehman, H.U.; Basra, S.M.; Rady, M.M.; Ghoneim, A.M.; Wang, Q. Moringa Leaf Extract Improves Wheat Growth and Productivity by Affecting Senescence and Source-sink Relationship. Int. J. Agric. Biol. 2017, 19, 479-484. [CrossRef]

31. Mbandlwa, N.P.; Fotouo-M, H.; Maboko, M.M.; Sivakumar, D. Stomatal conductance, leaf chlorophyll content, growth, and yield of sweet pepper in response to plant growth regulators. Int. J. Veg. Sci. 2019, 26, 116-126. [CrossRef]

32. Foidl, N.; Makkar, H.P.S.; Becker, K. The potential use of moringa oleifera for agriculture and industrial uses. In The Miracle Tree: The Multiple Attributes of Moringa oleifera; Fuglie, L.J., Ed.; CWS: Dakar, Senegal, 2001; pp. 91-195.

33. Nouman, W.; Siddiqui, M.T.; Basra, S.M.A. Moringa oleifera leaf extract: An innovative priming tool for rangeland grasses. Turk. J. Agric. For. 2012, 36, 65-75.

34. Jackson, M. Soil Chemical Analysis; Prentice Hall, Inc.: Englewood Cliffs, NJ, USA, 1962; p. 498.

35. Chapman, H.D.; Pratt, P.F. Methods of Analysis for Soils, Plants and Waters. Soil Sci. 1962, 93, 68. [CrossRef]

36. Bradford, M.M. A rapid and sensitive method for the quantification of microgram quantities of protein utilizing the principle of protein-dye binding. Anal. Biochem. 1976, 72, 248-254. [CrossRef]

37. Bates, L.S.; Waldren, R.P.; Teare, I.D. Rapid determination of free proline for water-stress studies. Plant Soil 1973, 39, 205-207. [CrossRef]

Publisher's Note: MDPI stays neutral with regard to jurisdictional claims in published maps and institutional affiliations.

(C) 2020 by the authors. Licensee MDPI, Basel, Switzerland. This article is an open access article distributed under the terms and conditions of the Creative Commons Attribution (CC BY) license (http://creativecommons.org/licenses/by/4.0/). 